\title{
Dioxin is an Insidious Toxin: The Role of Liposuction for the Blood Dioxin Levels
}

\author{
Sinsi Toksin Dioksin: Liposakşın Ameliyatının Kan Dioksin Seviyelerindeki Rolü
}

\section{Bora Ozel ${ }^{1}$, Seyhan Cenetoglu², Ayse Sencan ${ }^{3}$}

\footnotetext{
${ }^{1}$ Memorial Sisli Hospital Department of Plastic Reconstructive and Aesthetic Surgery, Istanbul, Turkey

${ }^{2}$ Gazi University Faculty of Medicine, Department of Plastic, Reconstructive and Aesthetic Surgery, Ankara, Turkey

${ }^{3}$ Bagcilar Training and Research Hospital Department of Hand Surgery, Istanbul, Turkey
}

\section{ABSTRACT}

Background: Dioxins are chemicals which remain intact in the environment for long periods, accumulate in fat tissues of living organisms and are toxic to humans. The aim of this study is determining the concentration of dioxin which passes from the adipose tissues to the bloodstream by means of liposuction, and comparing the results with the existing dioxin level in the blood in order to take certain precautions according to the obtained results.

Methods: From May 2012 to April 2013, blood values of 9 female patients, who underwent liposuction, were examined. Their blood samples were collected on three stages, once before the surgery, once on the day after the surgery and finally 3 weeks after the surgery. It was a tumescent liposuction performed on abdominal area. Dioxin levels were also measured from the adipose tissue obtained through liposuction. The dioxin toxic levels were measured by gas chromatography / tandem mass spectrometry.

Results: The results have demonstrated that serum concentration of dioxin significantly decreased after liposuction. (Preoperative 0.23 , postoperative 1 $0,17$, postoperative 300.15$)(p=0.007)$. Liposuction leads to a redistribution of dioxins and to a moderate decrease of their blood concentration. Epinephrine, a potent vasoconstrictor added to infiltrate solution, may inhibit dioxin uptake into the system circulation.

Conclusions: The results of this study have demonstrated that liposuction has a reducing function in blood dioxin levels. We believe that liposuction leads to a redistribution of dioxin and to a moderate decrease in the blood concentration which is possible to help to reduce toxic effects. This study is very important since it is the first report on dioxin contamination in human blood in Turkish society as well.

Key Words: Adipose tissue, dioxin, liposuction, toxic effects

Received: 07.15.2017

Accepted: 01.20 .2018
ÖZET

Amaç: Kalıcı organik kirleticilerin en toksik özelliğe sahip üyelerinden biri olan dioksinler; doğada çok zor parçalanma ve yağ dokularında depolanma özelliğine sahiptir. Bu çalışmanın amacı liposuction ameliyatı ile birlikte parçalanan yağ dokularından kana geçen dioksin toksininin düzeyini belirlemek ve bu sonucu yağ dokusunda var olan dioksin düzeyi ile karşılaştırmaktır. Amaçlardan bir diğeri ise liposuction ameliyatının dioksin toksininin vücuttan atılması için bir yöntem olup olamayacağı konusunun aydınlatılmasıdır.

Yöntemler: Çalışmada 2012-2013 yılları arasında vücut kitle indeksi 30 kg /m 2 den fazla olan 9 hastaya liposuction ameliyatı gerçekleştirilmiştir. Ameliyat öncesi, ameliyat sonrası 1 . gün ve ameliyat sonrası 3 . haftada kan ve ameliyat esnasında yağ dokusu örnekleri alınmış ve bu örneklerden dioksin analiz gerçekleştirilmiştir. Dioksin düzeyi ölçümlerinde gaz kromotografisi / kütle-kütle spektroskopisi (GC/MS-MS) sistemleri metodu kullanılmıştır.

Bulgular: Analiz sonuçları kan dioksin düzeyinin liposuction ameliyatı ile birlikte azaldığını göstermiştir. Bu azalma 1. günden itibaren başlamakta ve ilerleyen haftalarda da devam etmektedir. ( $p=0.007)$. Çalışmamızda dioksin toksininin ameliyat sonrası 1.günde alınan kan örneklerinde ameliyat öncesine göre daha düşük çıkması bu süreçte dioksinin dokulara yeniden dağılımı ile açıklanabilir. Yine ameliyat esnasında kullanılan adrenaline bağlı vazokonstrüktör etki ve parçalanan yağ hücrelerinin hemen aspirasyonun da etkili olduğu düşünülmektedir

Sonuç: Çalışamanın sonucunda liposuction ameliyatının kan dioksin seviyelerinin düşmesinde etkili bir yöntem olduğu gösterilmiştir. Dioksine bağlı muhtemel toksik etkilerinde bu yöntem sayesinde azalacağına inanıyoruz. Ayrıca bu çalışma Türk toplumunda ilk kez dioksin serum düzeyinin belirlenmesi açısından da öneme sahiptir.

Anahtar Sözcükler: Yağ dokusu, dioksin, liposuction, toksik etki

Geliş Tarihi: 15.07.2017

Kabul Tarihi: 20.01.2018

Address for Correspondence / Yazışma Adresi: Bora Ozel, MD Sisli Memorial Hospital Department of Plastic Reconstructive and Aesthetic Surgery Piyale Pasa Bulvarı Istanbul, Turkey E-mail: boraozel2007@yahoo.com

CTelif Hakkı 2019 Gazi Üniversitesi Tıp Fakültesi - Makale metnine http://medicaljournal.gazi.edu.tr/ web adresinden ulaşılabilir.

CCopyright 2019 by Gazi University Medical Faculty - Available on-line at web site http://medicaljournal.gazi.edu.tr/

doi:http://dx.doi.org/10.12996/gmj.2019.03 


\section{INTRODUCTION}

The dioxins are highly toxic environmental pollutants that are formed by some chemical processes and high temperature. The chemical structure of dioxin consists of two benzene rings which are connected by a third middle ring that consists of two oxygen atoms in the parapositions, and also have four to eight chlorine atoms attached. Very low levels of dioxin (parts-per-trillion, ppt, $\mathrm{pg} / \mathrm{g}$ ) occur widespread in the environment. There are 75 total dioxin compounds or congeners. 2,3,7,8- Tetrachlorodibenzo-para-dioxin $(2,3,7,8$ TCDD) has been intensively studied and known to be the most toxic compound among these compounds $(1,3)$. Because toxicity is mediated through the ary hydrocarbon receptor, a toxic equivalence factor (TEF) is used, assuming that the effects are additive and act via a common mechanism to cause toxicity.

Dioxins are very persistent in the environment as well as bioaccumulative and undergo biomagnification up to the food chain. In humans the half-life has been estimated to be 7-11 years (4). The metabolism of these compounds appear to be very slow; metabolites are excreted into the bile in the faeces (5). Dioxins are lipid soluble, lactation can reduce the level in the nursing woman. Unfortunately, this leads to increased exposure of the nursing infant (6).

Dioxins are involved reproductive disorders, immune function alterations, thyroid function impairments, chloracne, neurodevelopmental and neurobehavioral alterations as well as cancer with increasing cumulative exposure $(7,8)$. Therefore, dioxin exposure is frequently seen as a public health or epidemiological issue rather than a clinical issue. And the body burden can be correlated with adverse healthy effects (9).

Chloracne is the pathognomonic lesion when dioxin poisoning ceases. Chloracne is helpful, but very rare since its presence means that there has been an exposure to dioxin, but its absence does not show reverse (10).
Most typical evidence of dioxin intoxication is occurring chloracnes but only a small number of dioxin intoxication means that chlroacne would appear. All dioxins exert their physiological effects via high-affinity binding to the intracellular ligand-activated transcription factor AhR (aryl hydrocarbon receptor) (11). Binding of AhR leads to changes in gene expression, cell replication, and apoptosis $(1,12)$

In 2009, the International Agency for Research on Cancer (IARC) confirmed the classification of TCDD as a group 1 carcinogen, citing sufficient epidemiological evidence for all cancers combined $(13,14)$.

Body burdens of dioxins can be correlated with adverse healthy effects (10). The aim of our study is to determine the concentration of dioxin that passes from the adipose tissues to the blood stream by means of liposuction, and to compare the results with the existing dioxin in the blood so that certain precautions can be taken according to the obtained results.

\section{MATERIALS and METHODS}

Nine female patients, who underwent liposuction having a BMI exceeded 30 $\mathrm{kg} / \mathrm{m}^{2}$, were included in the study. The amount of liposuctioned material is at least $3000 \mathrm{~mL}$. Blood samples were collected before the surgery, on the day after and 3 weeks after surgery (Post I and Post II, respectively) in two 8-mI Vacutainer ${ }^{\mathrm{TM}}$ tubes containing EDTA. All samples were centrifuged at $3000 \mathrm{rpm}$ for 3 minutes within 1 hour after collection and plasma was removed and frozen at $-33^{\circ} \mathrm{C}$ in glass containers until shipped on dry ice to $A G$ Pur, in Izmir for analysis. Periumbilical surgical biopsies of subcutaneous adipose tissue were obtained by dry liposuction before infiltration. Table 1 presents the physical characteristics of the participants. All participants were informed about the study and issued their written approvals to participate in the study, which was approved by Gazi University Hospital Centre Medical Ethics Committee with a number of G.U ET-37/08.02.2012.

Table 1 :Physical characteristics of patients

\begin{tabular}{|c|c|c|c|c|c|c|c|c|}
\hline & Age & Weight & Height & BMI & $\begin{array}{l}\text { Amount of } \\
\text { Suctioned } \\
\text { volume }\end{array}$ & Occupation & $\begin{array}{l}\text { Smoking } \\
\text { history }\end{array}$ & $\begin{array}{l}\text { Breastfed } \\
\text { children }\end{array}$ \\
\hline 1 & 56 & 85 & 168 & 30.1 & 3000 & Nurse & Yes & Yes \\
\hline 2 & 45 & 82 & 164 & 30.5 & 3000 & Biologist & No & No \\
\hline 3 & 28 & 88 & 170 & 30.4 & 3000 & Secretary & Yes & Yes \\
\hline 4 & 34 & 91 & 172 & 30.8 & 3100 & Architect & Yes & Yes \\
\hline 5 & 40 & 80 & 161 & 30.9 & 3200 & Housewife & Yes & Yes \\
\hline 6 & 31 & 84 & 158 & 33.6 & 3500 & Textile worker & No & No \\
\hline 7 & 36 & 96 & 167 & 34.4 & 3500 & Babysitter & Yes & Yes \\
\hline 8 & 41 & 100 & 170 & 34.6 & 3500 & Housewife & No & Yes \\
\hline 9 & 44 & 120 & 176 & 38.7 & 3600 & Teacher & No & No \\
\hline
\end{tabular}

\section{Surgery}

All patients underwent laboratory analysis before the surgery, including the hemoglobin, hematocrit, glucose, urea and creatinine levels. All patients were administered inhaled general anesthesia and monitored with an urinary catheter, according to Rohrich's recommendations (15), during liposuction. After dry liposuction to collect 5-6 cc adipose tissue sample, a wetting solution was infiltrated subcutaneously. Wetting solution consisted of $10 \mathrm{ml}$ of a $2 \%$ lidocaine solution , and $1 \mathrm{mg}$ (1:1000) epinephrine, which was added to $1000 \mathrm{ml}$ lactated Ringer's solution. One surgeon carried out the liposuction with an aspirating machine, model Byron PT-PLT III 03055101, and Mercedes Trimed cannulas which were $3 \mathrm{~mm}$ in diameter.

\section{Laboratory tests}

Dioxins analyses were conducted using gas chromatography / tandem mass spectrometry (Agilent 7000 Triple Quadropole GC/MS System). Values are reported on a lipid-weight basis in parts per trillion (ppt).

\section{Statistical analysis}

The SPSS (V.11.0) software package for Windows (SPSS; Chicago, Illinois, USA) was used for statistical analyses of the data. Values were expressed as medians and as SDs. Multiple regression analysis was used to assess the connection between age, BMI, smoking history, breast feeding history blood and fat tissue dioxin concentration. Wilcoxon signed-rank test was applied for the comparison pre op-post op intragroup. The significant value was established as $p<0.05$.

\section{RESULTS}

The study was performed from May 2012 to April 2013. The average age of the patients was 45.5 , the average body mass index was $32.6 \mathrm{~kg} / \mathrm{m}^{2}$, the average height was $164 \mathrm{~cm}$ and the average weight was $85 \mathrm{~kg}$. The amount of liposuctioned material was between 3000 and $3600 \mathrm{~mL}$, with an average quantity of $3311 \mathrm{~mL}$.

The body burden of dioxins can be assessed by measuring dioxin levels in blood lipid.(16) As summarized in Table 2 and Table 3, regarding the serum levels analyzed, the serum concentration of dioxin (ppt) decreased after liposuction. (Mean Preop 0.231, Postop I 0.178 Postop II 0.156; p <0.05) 
Table 2. Dioxin serum concentrations in adipose tissue, pre-op, post op I and post op II

\begin{tabular}{cllll}
\hline Patients no & Adipose tissue & $\begin{array}{l}\text { Pre-op } \\
\text { serum }\end{array}$ & $\begin{array}{l}\text { Post-op. 1 day } \\
\text { serum }\end{array}$ & $\begin{array}{l}\text { Post-op.3months } \\
\text { serum }\end{array}$ \\
\hline $\mathbf{1}$ & 0.35 & 0.13 & 0.11 & 0.10 \\
$\mathbf{2}$ & 0.52 & 0.12 & 0.10 & 0.09 \\
$\mathbf{3}$ & 0.45 & 0.26 & 0.24 & 0.20 \\
$\mathbf{4}$ & 0.54 & 0.31 & 0.28 & 0.26 \\
$\mathbf{5}$ & 0.54 & 0.17 & 0.12 & 0.11 \\
$\mathbf{6}$ & 0.59 & 0.25 & 0.19 & 0.15 \\
$\mathbf{7}$ & 0.46 & 0.27 & 0.19 & 0.13 \\
$\mathbf{8}$ & 0.47 & 0.25 & 0.16 & 0.22 \\
$\mathbf{9}$ & 0.56 & 0.32 & 0.22 & $\mathbf{0 . 1 5 6}$ \\
Mean & $\mathbf{0 . 4 9 7}$ & $\mathbf{0 . 2 3 1}$ & $\mathbf{0 . 1 7 8}$ & \\
\hline
\end{tabular}

Statistically significant correlations were observed between age and adipose tissue dioxin levels. (correlation coefficient $\rho=0,866, p<0.05$ ). Several researchers investigated the factors associated with the blood levels of dioxins. Generally, blood concentrations of dioxin increase with age. (Table 4 . Associations of adipose tissue within dioxin levels for BMI, breastfeeding, smoking and age). Statistically significant correlations were observed between breastfed status and adipose tissue dioxin levels. (correlation coefficient $\rho=-0,756, p<0.05$ )

Table 3. Statistical analysis of mean levels of dioxin.

\begin{tabular}{llll}
\hline Pre.op & Post-op I & Post-op II & Adipose tissue \\
\hline 0.231 & 0.178 & 0.156 & 0.497
\end{tabular}

Table 4. Associations of adipose tissue within dioxin levels for BMI, Breastfeeding, Smoking and Age.

\begin{tabular}{lc}
\hline & Adipose tissue dioxin \\
BMI & $p=0.17$ \\
Breastfed & $p=0.01$ \\
Smoking & $p=0.17$ \\
Age & $p=0.003$ \\
\hline
\end{tabular}

\section{DISCUSSION}

Various attempts to reduce elevated human dioxin body burden have been made with little to no clinical success. Those include dietary intake of minera oil, activated charcoal, rice bran, and the fat substitute Olestra $(5,17)$. Thus, liposuction might be an effective treatment for dioxin intoxication. Furthermore liposuction may provide a therapeutic approach to reduce the body burden of dioxins.

We could explain how to decrease dioxin after liposuction as follows; First, epinephrine, a potent vasoconstrictor added to infiltrate solution, may diminish dioxin uptake into the systemic circulation (18). Blood samples were taken at Gazi University Faculty of Medicine and kept in -33C at serology laboratory of university's microbiology department. We know maximum epinephrine levels were observed 5 to 6 hours after induction which this duration is enough to finish the operation (19). Additionally, we can aspirate fragment adipose tissue with dioxin in it and dioxin removed in the liposuction aspirate.

Finally, dioxins are removed rapidly from the blood and distributed to liver, adipose tissue and other tissues within the first hour(s) after exposure. Abraham et al. examined the concentration of TCDD in liver and adipose tissue of female Wistar rats over a 91-day period after a single subcutaneous exposure at a dose of $300 \mathrm{ng} / \mathrm{kg}$. The maximum concentration of TCDD in the liver and adipose tissue was reached 3 and 7 days after exposure, respectively (20).

Dioxin levels in human serum are age-dependent (21). We observed statistically significant, age increased dioxin levels. Since the half-lives are very long (for e.g. TCDD 7-8 years), the body burden will increase almost the entire lifetime. Therefore the concentration may increase 5-to 10-fold from age 20 to age 60 (1).

There was a small tendency for BMI to show greater concentrations, we observed a very weak connection between BMI and the dioxin levels because it has been demonstrated that age has an effect on blood concentration of dioxin. Under these circumstances, the dioxin body burden will increase and be reflected in a higher serum dioxin concentration. Serum dioxins are in a passive pharmacodynamics equilibrium with the adipose reservoir of the individual (22)
These results suggest that age is the important factor predicting the initial total plasma dioxin concentration, not BMI. This observation confirms results presented in several studies $(16,21,23,24)$.

Dioxins are lipid soluble, lactation can reduce the level in the nursing women [10].Similarly to our report, significant positive associations of dioxin levels with breast-feeding. No correlation was observed between smoking habits and dioxin levels.

Being the main source of energy and free fatty acids, subcutaneous fat has different metabolic implications than visceral adipose tissue. Studies in human suggest that large-volume liposuction could increase the proportion of visceral adipose tissue (25). Dioxin content in different adipose tissue territories was similar although visceral and subcutaneous fat territories display different metabolic properties (26). Post liposuction decreased serum levels of dioxins, is probably because adipose tissue compensatory increases in the size of remaining depots. Matarasso et al studied the impact of liposuction on body fat in 63 patients. Large volume liposuction removed relatively little body fat, leading to significant increases in the proportion of visceral adipose tissue (27). Removal of 10 to 12 percent of subcutaneous adipose tissue resulted in an increased proportion of visceral adipose tissue in both women and men 12 and 14 percent, respectively. Trials on animals and patient reports imply compensatory increases in the size of remaining depots and metabolic changes after removing amounts of fat varying between 10 and 25 percent. After liposuction, the adipose tissue increases its protective role and depots much more dioxins, dioxins level decreased (24-28).

In recent years, there has been an increasing interest in autologous fat grafting for aesthetic and reconstructive purposes (29). There is no visible evidence that autologous fat grafting affects the efficacy of cancer $(30,31)$. The biological mechanism of tissue regeneration is not completely figured out, further in vitro, in vivo, and clinical trials are needed to develop a more extensive understanding of the benefits and potential risks of lipoaspirate transplant in oncologic patients $(32,33)$. We need further studies to be aware of the potential oncological risk of dioxin while fat grafting.

Currently, the level of dioxin in general American and European population is approximately< 1-2 ppt, which is age related. These levels have been declining in the past three decades (34). The results suggest that human background contamination by dioxin in non-industrialized countries is lower than that generally found in industrialized countries (35). This is nearly a certain outcome of stricter regulations of industrial processes throughout the developed world (10). A study of polychlorinated dibenzo-p-dioxins (PCDDs), polychlorinated dibenzofurans (PCDFs) and polychlorinated biphenyls (dl-PCBs) was conducted in breast milk from primiparous mothers living in 12 locations in the industrial area of southern Rio de Janeiro, Brazil between August 2012 and July 2013 by a questionnaire about nutrition and living conditions. Breast milk was collected between four and six weeks after delivery from mothers. The toxic equivalency (TEQ) of PCDD/Fs, and dl-PCBs were 10.6, 4.77, 6.96 TEQ pg/g, respectively. The understanding and identifying of pollution sources may be helpful to apply better countermeasures against breast milk dioxin contamination. The background contamination by PCDD/Fs, and dl-PCBs in mothers living in industrial area in Rio de Janeiro is lower than that generally found in industrialized countries. 
The study describes a potential application for liposuction. The number of patients in this study was few, and all patients were female who live in major cities. We have no data to suggest that the lower blood levels that we found on day 1 and 21 do not increase due to other factors. We have no data for post op tissue dioxin levels. Because of absence of permissions to undergo any operations. Future studies are warranted in which male and female patients are included. We believe that liposuction leads to a redistribution of dioxins and to a moderate decrease in the blood concentration that might help to reduce toxic effects.

\section{CONCLUSIONS}

The results of this study have demonstrated that liposuction has a reducing function on blood dioxin levels. We believe that liposuction leads to a redistribution of dioxins and to a moderate decrease in the blood concentration which might help to reduce toxic effects. This study is very important since it is the first report on dioxin contamination in human blood of the Turkish population as well.

In 2004, dioxin toxicity became a world agenda topic once again on the occasion of the Ukrainian president Victor Yushchenko being poisoned with it. He was offered a liposuction operation which he refused due to lack of scientific studies and its effects being unknown, by then. Our study is designed to fill up this gap. The results of this study have demonstrated that liposuction has a reducing function in blood dioxin levels.

\section{Acknowledgements}

This research is financially supported by Gazi University Research Fund (Project no 01/2012-34)

\section{Conflict of interest}

No conflict of interest was declared by the authors.

\section{REFERENCES}

1.Lindén J, Lensu S, Tuomisto J, Pohjanvirta R. Dioxins, the aryl hydrocarbon receptor and the central regulation of energy balance Frontiers in Neuroendocrinology 2010;31:452-78.

2.Davy CW. Legislation with respect to dioxins in the workplace 2004;30:219-33. 3.Yoshida R, Ogawa Y. p -dioxin : An Application of Oxidative Stress Markers to Cancer Risk Assessment of Dioxins 2000:5-14.

4.Kang HK, Watanabe KK, Breen J, Remmers J, Conomos MG, Stanley J. Dioxins and Dibenzofurans in Adipose Tissue of US Vietnam Veterans and Controls $1991 ; 81$.

5.Sorg O, Zennegg M, Schmid P, Fedosyuk R, Valikhnovskyi R, Gaide O, et al. 2,3,7,8-tetrachlorodibenzo-p-dioxin (TCDD) poisoning in Victor Yushchenko: identification and measurement of TCDD metabolites. Lancet 2009;374:117985.

6.Todaka T, Hirakawa H, Kajiwara J, Onozuka D, Sasaki S, Furue M. Chemosphere Concentrations of polychlorinated dibenzo-p-dioxins, polychlorinated dibenzofurans, and polychlorinated biphenyls in blood and breast milk collected from pregnant women in Sapporo City , Japan. Chemosphere 2011;85:1694-700. 7.Steenland K, Deddens J, Piacitelli L. Risk assessment for 2,3,7,8tetrachlorodibenzo-p-dioxin (TCDD) based on an epidemiologic study. Am J Epidemiol 2001;154:451-8.

8.Muenyi CS, Carrion SL, Jones LA, Kennedy LH, Slominski AT. Effects of In utero exposure of C57BL/6J Mice 2,3,7,8- Tetrachlorodibenzo $p$-dioxin on Epidermal Permeability Barrier Development and Function. Environ Health Perspect 2014;122:1052-9.

9.Dioxin: Disposition and pharmacokinetics. Review 2003 December 1-114. Avaible from:

https://cfpub.epa.gov/ncea/iris drafts/dioxin/nas-

review/pdfs/part2/dioxin pt2 ch01 dec2003.pdf.

10.Schecter A, Birnbaum L, Ryan JJ, Constable JD. Dioxins: an overview. Environ Res 2006;101:419-28.
11.Matsumura F. On the significance of the role of cellular stress response reactions in the toxic actions of dioxin. Biochem Pharmacol 2003;66:527-40. 12. Hahn ME. Aryl hydrocarbon receptors: diversity and evolution. Chem Biol Interact 2002;141:131-60.

13.Warner M, Eskenazi B, Mocarelli P, Gerthoux PM, Samuels S, Needham L, et al. Serum Dioxin Concentrations and Breast Cancer Risk in the Seveso Women's Health Study. Environ Health Perspect 2002;110:625-8.

14.Baan R, Grosse Y, Straif K, Secretan B, El Ghissassi F, Bouvard V, et al. A review of human carcinogens-Part F: Chemical agents and related occupations. Lancet Oncol 2009;10:1143-4.

15.R.J.Rohrich SJB. Is liposuction safe. Plast Reconstr Surg 1999;104:819-26. 16.Kokichi arisawa, Hideo takeda $\mathrm{H}$ mikasa. Background exposure to PCDDs PCDFs PCBs and its potential health efffects : a review of epidemiologic studies. J Med Investig 2005;52:10-21.

17.Moser GA, Mclachlan MS. A non-absorbable dietary fat substitute enhances elimination of persistent lipophilic contaminants in humans. Chemosphere 1999;39:1513-21.

18.Iverson RE, Pao VS. MOC-PS(SM) CME article: liposuction. Plast Reconstr Surg 2008;121:1-11.

19.Kenkel JM, Lipschitz AH, Luby M, Kallmeyer I, Sorokin E, Appelt E, et al. Hemodynamic Physiology and Thermoregulation in Liposuction. Plast Reconstr Surg 2004;114:503-13.

20.Viluksela M, Duong T V, Stahl BU, Li X, Tuomisto J, Rozman KK. Toxicokinetics of 2,3,7,8-tetrachlorodibenzo-p-dioxin (TCDD) in two substrains of male LongEvans rats after intravenous injection. Fundam Appl Toxicol 1996;31:184-91. 21.Voorspoels S, Covaci A, Maervoet J, Schepens P. Relationship between age and levels of organochlorine contaminants in human serum of a belgian population. Chemosphere 2002;69:22-9.

22. Wolff MS, Anderson HA, Fat B, Cancer D, Biomark E. Correspondence re : J . M . Schildkraut et al ., Environmental Contaminants and Body Fat Distribution . Cancer Epidemiol . Biomark . Prev1999: 179:951-2.

23.Schildkraut JM, Demark-Wahnefried W, DeVoto E, Hughes C, Laseter JL, Newman B. Environmental contaminants and body fat distribution. Cancer Epidemiol Biomarkers Prev 1999;8:179-83.

24. Hue O, Marcotte J, Berrigan F, Doré J, Marceau P, Tremblay A, et al. Increased Plasma Levels of Toxic Pollutants Accompanying Weight Loss Induced by Hypocaloric Diet or by Bariatric Surgery 2006:1145-54.

25.Mauer MM, Harris RB, Bartness TJ. The regulation of total body fat: lessons learned from lipectomy studies. Neurosci Biobehav Rev 2001;25:15-28.

26. Kim M-J, Marchand P, Henegar C, Antignac J-P, Alili R, Poitou C, et al. Fate and complex pathogenic effects of dioxins and polychlorinated biphenyls in obese subjects before and after drastic weight loss. Environ Health Perspect 2011;119:377-83.

27.A.Matarasso, R.W.Kim JGK. The impact if liposuction on body fat. Plast Reconstr Surg 1998;102:1686-9.

28. Esposito K, Giugliano G, Scuderi N, Giugliano D. Role of adipokines in the obesity-inflammation relationship: the effect of fat removal. Plast Reconstr Surg 2006;118:1048-57; discussion 1058-9.

29.Rigotti G, Marchi A, Stringhini P, Baroni G, Galiè M, Molino AM, et al. Determining the oncological risk of autologous lipoaspirate grafting for postmastectomy breast reconstruction. Aesthetic Plast Surg 2010;34:475-80.

30.Pearl R a, Leedham SJ, Pacifico MD. The safety of autologous fat transfer in breast cancer: lessons from stem cell biology. J Plast Reconstr Aesthet Surg 2012;65:283-8.

31.Lohsiriwat V, Curigliano G, Rietjens M, Goldhirsch A, Yves J. Autologous fat transplantation in patients with breast cancer: " silencing" or " fueling " cancer recurrence ? The Breast 2011;20:351-7.

32.Vona-Davis L, Rose DP. Adipokines as endocrine, paracrine, and autocrine factors in breast cancer risk and progression. Endocr Relat Cancer 2007;14:189206.

33.Perrot P, Rousseau J, Bouffaut A-L, Rédini F, Cassagnau E, Deschaseaux F, et al. Safety concern between autologous fat graft, mesenchymal stem cell and osteosarcoma recurrence. PLoS One 2010;5:e10999.

34.Cok ismet, Donmez M, Satiroglu H.Aydinuraz, Kabukcu, Henkel I. levels of dioxin-like PCB congeners in adipose tissue of Turkish men. JPHARMSCi 2006:710.

35.Shen H, Han J, Tie X, Xu W, Ren Y, Ye C. Polychlorinated dibenzo-pdioxins/furans and polychlorinated biphenyls in human adipose tissue from Zhejiang Province, China. Chemosphere 2009;74:384-8. 